\title{
Method Selection, Basic Methods and Different Orientations in Foreign Language Teaching
}

\author{
Bünyamin Celik ${ }^{1}$ \\ ${ }^{1}$ Department of Languages, Ishik University, Erbil, Iraq \\ Correspondence: Bünyamin Celik, Ishik University, Erbil, Iraq. \\ Email: bunyamin.celik@ishik.edu.iq
}

Received: January 5, 2019 Accepted: February 24, $2019 \quad$ Online Published: March 1, 2019

doi: 10.23918/ijsses.v5i3p237

\begin{abstract}
The greatest feature that distinguishes a person living on Earth from other living things is undoubtedly the ability to communicate in very different ways. Human beings recognize and introduce themselves through language. According to (Aksan 2003) "language is a multi-faceted developed symbolic group that allows thoughts, feelings and aspirations to be transmitted to others by making use of items and rules common to voice and meaning in a society" (p. 11). People communicate in their own societies through their languages. When people living in different societies and when different settlements come together to communicate with each other, each community has become familiar and ordinary with a different language for another society. Thus, the need for people to learn a foreign language has emerged. The subject of this study is different orientations in foreign language teaching. The aim of the study is to explore the different language learning methods and method selection that need to be used in the target foreign language teaching of people who show differences even in their own common culture as well as the basic approaches used in foreign language education since the foreign language learning has become a necessity nowadays in the ever.
\end{abstract}

Key words: Methods, Foreign Language Teaching Methods, Foreign Language Teaching

\section{Introduction}

The first language we learned is mother language. The second language we learn is called foreign language. The most important difference between the two is that, we learn the mother tongue with the subconscious processes and we learn foreign language with conscious processes. Throughout the history of humanity, language has become a reflection of everything that belongs to the nature and life of man. Although we see it as a communication tool, it is actually more than a tool; it is a systematic way of expressing meaning. It involves the self-management, socialization, cultural, educational and development processes of self from childhood to the adulthood. Halliday (1978) defines language as a "social display" where culture is hosted, and each language speaks to the society in which it is spoken, reflecting concepts such as life style and the way of thinking. Each language has its own elements with its own rhythm and spirit, as well as the cultural elements it recognizes in itself. In short, every language is a wealth. The skill of man's language acquisition is based on the experience of thousands of years. Language comes first as a voice, then as a word, then as a syntactic word.

The reason for learning foreign languages can be the same or different. However, the form, intelligence, personal traits, learning and perception skills, emotional approaches, and the ability to learn a new foreign language are utterly different for people who learn foreign languages. No matter how important 
the reason for learning the target foreign language is, it is not enough for this individual to learn a foreign language. With these differences in mind, the best way to make people want to learn a foreign language is to teach them how to learn.

Especially after the Second World War, the colonization and a mass migration of professionals, different kinds of methods and techniques in teaching foreign languages were started to be taken into consideration, and the researches and experiments of scientists in different fields are still going on. In general, in 1920, while abstract and theoretical issues were dealt with, linguistics was applied in the 1940s and in the 1950s, science branches such as psychology, anthropology, and sociology were recognized, which had an impact on foreign language teaching. This interaction has resulted in mixed science branches such as psychology, anthropological linguistics, sociology, and education-linguistics. It is impossible to separate foreign language teaching from these disciplines because many foreign language teaching methods have to use one of the theories of linguistics and learning. In this study, we will examine the methods and methodology applied in the name of different and better foreign language teaching as well as the basic methods and approaches generally adopted and applied in foreign language education.

\section{Basic Methods in Foreign Language Teaching}

In this study, Grammar-Translation, Direct Method, Audio-lingual Method, Natural Method, Communicative and Cognitive Methods applied in foreign language teaching are explained as the basic methods since the methods belong to the 19th century and recent periods are taken into consideration in general.

\subsection{Grammar-Translation Method}

This method aims at written communication, not verbal. As nearly the oldest methods in the historical development of foreign language teaching methods and approaches, grammar-translation is based on the principle of teaching the language rules. It is also called the classical method because it was used in the 16th century during teaching Latin and Greek. Richards and Schmidt (2002, p. 231) have defined the grammar-translation method as "a method of foreign or second language teaching which makes use of translation and grammar study as the main teaching and learning activities." Grammar-language method is a traditional method that was used a lot until XX. century. This teaching method was based on grammatical rules based on memorization and deduction. According to Richards and Rodgers (2001, p. 6), "Grammar Translation dominated European and foreign language teaching from the 1840s to the 1940 s, and the modified form is still widely used in the world today."

In the Grammar-Translation Method, the grammatical forms in the passages first taught to the students. The grammar is learned by examining the given text. Teaching is often is with the mother tongue. Foreign language is used less than mother tongue. It is essential that the learner develop his/her vocabulary. For this reason, the list of words given from the selected text is memorized by the students. This will increase the vocabulary of the student. The pronunciation is not very important. For this reason, pronunciation is mostly not included in the exercises (Demirel, 2003). Mixed and difficult grammatical structures are given in detail. It is possible to learn the language by learning sentence patterns and grammar. When the rules are taught, verb conjugation, translation, and independent sentences are used. Translation is done after reading. At first translation starts with easy classic works 
and then difficult and complex works. It was believed that translation would provide clarity in language learning which would play a major role in the development of accuracy (Mart, 2013a). The content of the text is not very important. The text in terms of grammatics, carry exercise character. The important thing is the sentence patterns in the text.

\subsection{Direct Method}

The direct method emerged in France and Germany in the 1950s in response to the grammar-translation method. This method, which is also called natural method in many places, is a method which refuses to use the mother tongue of the students and uses only the target language. The direct method was based on the assumption that language is best learnt when it is actively used by learners; thus, conversational activities hold a significant place in this method for the development of oral proficiency (Mart, 2013b). According to this method, the language will be heard by the ear first and then will be reinforced by the tongue and read and written by hand. According to Naik (2013), in direct method application; Visual and direct visual relationships are established between teachers' mental and physical abilities, experience and performance practices and learning goals. The direct method of teaching a language is to establish a direct and visual connection between experience and expression, words and expressions, idioms and meanings, rules and performances, through the teachers' bodies and mental abilities, without any help from the mother tongue of the students.

Gouin's views on language teaching have been influential in the emergence of this method. The way of language teaching; hearing is the first step, it will be reinforced by the tongue and practically read and written. The first opinions on the development of four basic skills in foreign language teaching were raised by Gouin. Gouin sees foreign language teaching as physical activity (learning by doing) (Demirel, 1993).

This method has become a widely used method in West Africa. It has been desired to be applied and disseminated in other countries, but its implementation has brought many difficulties and various applications together. This method starts with a dialogue or a motivational introduction. Grammar and new words are given verbally because the teaching is first made orally. The teaching of the words is done by word definition, by pantomime or by visual means. Grammar structures are given by induction method. Grammar is tried to be given in suitable mediums using visual means. This method allows the language to be learned to be used effectively. In the first weeks of the course, the pronunciation is taught a lot. At the same time new grammatical structures are taught while listening and repeating. The reading comprehension includes the cultures and the life of the language being taught. Teaching how to read is a preference rather than reinforcing grammar.

\subsection{Audio-lingual Method}

The audio-lingual method has emerged as a US-based teaching with the influence of behavioral psychology. Learning the language in the audio-lingual habit method is the period of strengthening the effect-response bond by reinforcing the correct answer. It was emerged between 1930 and 1950, with behavioral psychologists and structuralist linguists (Demirel, 1993). It is known as the ear-language habit method. In this method, what is said is repeated as the practice and produces sentences resembling sentence patterns and memorized through repetition. This method emphasizes verbal foreign language 
teaching. Grammar is taught in sentences. The audio-lingual method does not emphasize the presentation of grammar knowledge as in the grammar-translation method, but it does not find it completely wrong.

Audio-lingual method involves listening and repeating, often in choral format with all class members repeating language elements orally in unison (Larsen-Freeman \& Anderson, 2011), a technique that has a practical appeal to the low-technology classroom. It therefore rejects the problem-solving approach of the grammar-translation method and does not consider it appropriate to prioritize features such as word types or word lists. In the teaching order, listening and speaking is prior to reading and writing. Efforts are made to develop target language skills without using the native language. This method is also seen as a habit acquisition and conditioning phenomenon in which any intellectual analysis does not interfere with learning. Emphasis is placed on factors and simple practices. The aim is to alleviate the cognitive burden on the learner and enable them to learn through repetition and imitation, which is more effortless and repetitive.

\subsection{Natural Method}

The natural method advocates the necessity of teaching the foreign language as the mother tongue. The basis of the approach is "language acquisition". In a very simple and narrow sense, the natural approach claims that "a foreign language is acquired just like a child acquires his / her mother tongue". The first explanations of the natural approach of the 1970s and the first proposal for teaching foreign languages were put forward by Stephen Krashen, one of the applied linguists of the University of Southern California (Cuq, 2003).

In the method, the choice of the teacher is made among the people whose mother tongue is the language being taught. For this reason, the teacher uses his / her mother tongue and the speech is in the foreground. The teacher does not speak a language other than the taught language. Also, when communicating via speech, grammar rules are not given.

Reading and writing exercises are not included in this method when listening and speaking activities are conducted. The natural method emerged as a reaction to the grammar translation method. The student listens more during the teaching process. The student should speak as if she is in the mother tongue learning and ignore the mistakes. Vocabulary learning is a priority in language learning (Demircan, 2002; Demirel, 2003). In addition, some dialogues are memorized to improve speech skills. The words are not given separately but in the same sentence.

\subsection{Communicative Method}

According to this method, the main purpose of language learning is to provide verbal and written communication which is the basic function of the language. In that case, it is important to use it as a means of communication rather than language rules. Therefore, by arranging the communicative functions of the language in the academic sense, the organization of teaching style, tools, teacher and student roles and behaviors, class activities and applications are called "communicative approach" (Demircan, 1990).

According to the advocates of this method, instead of memorizing patterns, students should be guided to understand what they have learned. The aim here is to make sure that students understand and apply what they understand. It is not enough to know the sentence establishment rules in order to claim that the 
language is learned. It is also necessary to know what these terms can mean. The teacher is not the absolute authority in the classroom. Teaching is student centered. The task of the teacher is to enable the students to communicate appropriately for their purposes. The material to be taught must be of a quality that can be reconciled with what the student has learned before. Documents that are written on the target language on daily basis are used.

In the communicative approach, no priority is given to any skill. The curriculum is organized according to the communicative choices of students in listening, reading, speaking and writing areas (Berard, 1991). This method makes it clear that effective communication relies on the use of language skills competently (Mart, 2018). This approach can be applied only if the appropriate environment is available. Teachers have a great task in providing this environment. The teacher helps the students to communicate appropriately for their purposes.

In communicative approach to language teaching, teachers and students take roles outside traditional teacher-student understanding. As the communication processes are emphasized instead of teaching linguistic forms in such teaching, the learner himself/herself provides the compromise between the learning process and learning purpose. The teacher has two main roles. The first role is to facilitate the communication process between the participants and the various activities among all participants in the class, and the second role is to act as an independent participant in the learning-teaching group (Berard, 1991).

\subsection{Cognitive Method}

The learning of a language according to this method involves the pronunciation, grammatical and linguistic aspects of the structure of this language. Once the student reaches the cognitive control of these elements at a certain level, they will be able to spontaneously improve its ability to use and capacity in real situations. According to Murcia (1991) on the one hand, this method permits meaningful practice and language use, on the other hand, foresees a grammatical teaching program and does not consider language learning as an attempt to create habits. This method is based on the idea that grammar is important and presents the rules by deductive or induction method depending on the preference of the learner. The aim of the in-class exercises is to give examples about the rule applications.

Scientists embracing cognitive learning in foreign language teaching, on the other hand, are rational, as opposed to behavioralists who are motivated by the influence / reaction to learning. In other words; instead of memorizing learning, they make a foreground of meaningful learning. The mind transforms the learned items into meaningful units and establishes a relationship with what has been learned. While using this method, mechanical exercises are avoided, instead; it is aimed to use living, production, active and creative language. Generally speaking, cognitive method; is based on learning a language with its rules, consciously, rather than a habit. Listening skills are emphasized. Everything is taught in an integrity. It is equally important to teach each of the four basic skills. The use of the mother tongue and translation is free and the role of the teacher is to facilitate learning.

\section{Different Methods Used in Foreign Language Teaching}

As foreign language teaching is closely related to every humanitarian science branch, the developments in each of these branches of science and the emerging of new concepts have also directly or indirectly influenced the teaching of foreign languages. These methods exemplify the methods used in particular in 
the United States and Europe. In general, these methods and techniques have less application space and time.

\subsection{Silent Method}

It is a discovery learning approach invented by Caleb Gattegno at the beginning of the 1970s. According to Garttegno, the most important difference of this method from other methods is; instead of giving weight to teaching, learning is a priority. It is based on the use of colored tables and colored bars that are used as the main tool in the guidance of the students with the supervision of the teacher. Teacher conduct the lesson via using bars. Initially, the bars are introduced. Then the colors of the bars are taught. Colors express a voice. With the help of the bars, the students are asked to understand the commands given by the teacher in a quiet environment. The teacher is largely silent and provides more space for students to explore the language.

Students are responsible for their own learning and are encouraged to express themselves. One of the first aims is to provide a basis for foreign language grammar for independent learning. Although this method developed by Gattegno is not originated from the cognitive method, it shares certain principles with the cognitive method. The emphasis is on learning rather than teaching (Demircan, 2002; Demirel, 1993).

\subsection{Eclectic Method}

The Eclectic Method has been proposed as a response to dogmatism, which is often found in the intensity of teaching methods in the 1970s and 1980s. Focusing to a specific method in language teaching brings various limitations to teachers. In the foreign language teaching, choosing the most successful aspects of the methods applied up to this day and choosing the most efficient and harmonious way to apply is called the eclectic method. The idea of choosing from different methods for the teaching purposes and situations is not a new phenomenon. For example, Memorandum on the Teaching of Modern Languages published in 1929 on the basis of a British study by Incorporated Association of Assistant Masters in Secondary Schools exhorted the eclectic "Compromise Method" as a solution to the language teaching method debate (Stern, 1983, p. 101).

A main defender of the Eclectic Method is Rivers (1981). According to Rivers, Eclectic method gives authorization to language learners and teachers "to absorb the best techniques of all the well-known language-teaching methods into their classroom procedures, using them for the purposes for which they are most appropriate" (p. 55). Generally speaking, language skills in practice are handled as speaking, writing, listening comprehension and reading comprehension. Activities are oral exercises, reading out loud and question-answer. According to this method, translation and grammar take place in language teaching. On the other hand, according to Stern (1983) the main difficulty of this method is that "it does not offer any guidance on what basis and by what principles aspects of different methods can be selected and combined" (p. 512). The success of this method depends on the teacher being creative, energetic and willing to know the methods and techniques used in foreign language teaching until now.

\subsection{Suggestopedia Method}

This method was developed by Bulgarian psychiatrist Lozanov after 1960. Suggestopedia was developed by the Bulgarian psychiatrist-educator Georgi Lozanov (1978), who claims that people can learn at least 
three to five different languages quickly with traditional teaching methods with removing psychological obstacles that block learning while learning foreign languages. Lozanov has benefited from yoga and psychology for this method. The method aims to learn quickly. In this context, the method reveals the hidden creative features of the foreign language learner. According to Lozanov and Gateva (1988), the moment when performance of learning is the highest, is somewhere between conscious and unconscious. According to this claim, there is a point where the level of individual learning is the highest. If this point is reached at the moment of learning, the information will stay in memory for a longer time and be ready to be used.

It is believed that if a person who starts to learn a foreign language is able to reach the highest level of learning with suggestions, the information loads that can be made from that point on to the person will be saved and will not be forgotten again. Lozanov (1995), following that claim, suggested to the students that before the lesson they a new identity and a new name. The daily conversations are given also with music. For this reason, the method involves a mystical environment because music and musical rhythm is an important factor in learning. At the same time, the teacher shows an authoritarian attitude. The reason for this is that an authoritarian structure has improved the learning.

Dialogue in the method of suggestion takes an important place. When the dialogue is given to the student, the entire dialogue is read first. On the second step, attention is drawn to the emphasis and definitions, and this time it is read with music, and if necessary, with explanations in the mother tongue. On the third stage, the students are asked to keep the dialogue in their memories with their eyes closed with music. The use of music is the same as the usage of therapy.

\subsection{Total Physical Response "TPR" Method}

The Total Physical Response "TPR" Method was developed in 1960 by psychologist James Asher of San Jose State University in California. According to Asher (1966), the physical response comes before the verbal response. Teaching foreign language with this method is done with commands because these orders reveal the physical reaction. The student responds physically to the order given by the teacher. For this reason, the teacher is the director and the student is the player. In this method, materials are not used for beginners. The mimic and movements of the teacher are seen enough. But in the future, posters, slides and paintings are used.

In addition, foreign language teaching is identified with native language learning. In lessons, special attention is given to the analysis of words that are heard before, as a child learns the mother tongue. The designated purposes are action-based type exercises. Reading and writing activities are followed by oral command practice. At first, much importance is given to meaning than the form. Grammar is taught by induction, words are selected according to their usage frequency and class availability. According to Asher (1969), at the beginning, student mistakes are tolerated and the students are corrected, as they progress in language in a way that they are not psychologically disturbed.

\section{Method Selection in Foreign Language Teaching}

The fact that foreign language teaching covers other branches of science brought lot of methods with it. While many of these methods have reached today, many of them have failed to survive in the face of unsuccessful experiments and observations. At the same time, the concept of technique and method has always been compared with each other. 
As a matter of fact, although the method and the technical concepts are used in foreign language teaching, there is always a conceptual confusion that they are not completely differentiated. In this case, when the methods and techniques are elaborated, the method is the way to achieve the goal. Technique is the method of application. For this reason, it is necessary to use some teaching techniques in order to apply the teaching method which is used for the student to reach the goal while learning. In this context, we can say that the teaching technique is a way of putting the teaching method into practice. We can understand here that teaching methods and techniques are separate concepts.

Learning a foreign language is synonymous with having four basic skills (listening, speaking, reading, and writing). The diversity of foreign language teaching methods both in theory and practice is due to the fact that which one of these four basic skills are given priority, or in other words, whether it focuses on written communication or verbal communication. (Coste, 1995; Cuq, 2003)

Over the centuries, when consecutive teaching principles and methods are examined, it is seen that foreign languages do not change, but the priorities of students and teachers change. There are many disciplines contributing to the change of these priorities and the emergence of new teaching approaches. (Bange, 2005; Coste, 1995)

Language learning methods have crucial values for second language learners because they are tools for effectiveness and self-assessment. These methods and approaches can help advance and improve communication skills. Surveys show that learners of all levels use different methods, but most learners or students do not know exactly what method they use, or the most useful methods (Oxford, 1989).

First of all, taking into account the reasons for learning foreign languages in foreign language teaching will make important contributions to the achievement of previously planned objectives in the specified time period of foreign language teaching (Michel, 2005). The specified instructional objectives play an important role in which skills should be prioritized. If one of these four basic skills -listening, speaking, reading and writing need to be taught firstly according to teaching objectives, appropriate methods are needed. Reading skills are one of the basic skills in both native and foreign language teaching. On the other hand, communicative approaches can be used if conversational skills are to be taught. However, it is not considered a proper approach to distinguish four skills in foreign language teaching from each other with certain lines. (Demircan, 2002; Demirel, 2003a)

When it comes to choosing a method of teaching a foreign language, the way to effectively utilize the accumulation of existing knowledge should be chosen, rather than two opposing axioms, such as rejection or acceptance. This can be made possible by foreign language tutors equipped with the necessary knowledge about theoretical approaches and their transformation into practice within the concept of the method (Iş1k, 2005).

\section{Conclusion}

Choosing the appropriate method or approach, by taking into account all the circumstances in the teaching environment, is not sufficient for foreign language teaching neither for the teacher and the student. The appropriate method or approach should be supported by appropriate foreign language teaching techniques. In addition, the teacher should use the appropriate aspects of each method according to the current situation in the classroom and the needs of the students. In this context, the idea 
of using an appropriate method for each learning situation is more important than relying on a single method in the language teaching process.

\section{References}

Aksan, D. (2003). Her yönüyle dil ana çizgileriyle dilbilim. I, II, III Cilt, TDK Yayınları.

Asher, J. J. (1966). The learning strategy of the total physical response: A review. Modern Language Journal, 50, 79-84.

Asher, J. J. (1969). The total physical response approach to second language learning. Modern Language Journal, 53, 3-17.

Bange, P., Carol R., \& Peter Griggs, P. (2005). L'Apprentissage D'Une Langue Étrangère - Cognition et Interaction, L'harmattan.

Berard, E. (1991). L'Approche communicative. NY: CLE International Breach Science Publishers.

Coste D. (1995). Vingt ans dans l'évolution de la didactique des langues. Hatier/Didier

Cuq J. P. (2003). Dictionnaire didactique du français langue étrangère et seconde. CLE

Demircan, Ö. (2002). Yabancı dil ögretim yöntemleri. Der Yayınları.

Demirel, Ö. (1990). Yabancı dil öğretimi ilkeler yöntemler teknikler. USEM Yayınları

Demirel, Ö. (1993). Genel ögretim yöntemleri. USEM Yayınları.

Demirel, Ö. (2003). Yabancı dil öğretimi. Ankara: Pagem A Yayınları.

Demirel, Ö. (2003a). ELT methodology. Pegem A Yayınları.

Halliday, M. A. K. (1978). Language as social semiotic: the social interpretation of language and meaning. Sydney: Edward Arnold.

Işık, A. (2005). Bir yabancı dil nasıl öğrenilir. KHO Yayınları.

Larsen-Freeman, D., \& Anderson, M. (2011). Techniques and principles in language teaching (3rd ed.). Oxford, England: Oxford University Press.

Lozanov, G. (1978). Suggestology and outlines of suggestopedy. New York: Gordon and Breach.

Lozanov, G. (1995). Suggestology and outlines of suggestology (Rev. ed.) (M.H. Pozharlieva \& K. Pashmakove, Trans.). Amsterdam, The Netherlands: Gordon and Breach Publishers.

Lozanov, G., \& Gateva, E. (1988). The foreign language teacher's Suggestopedic manual. Gordon and Breach Publishers.

Mart, C.T. (2013a). The Grammar-Translation Method and the use of translation to facilitate learning in ESL classes. Journal of Advances in English Language Teaching, 1(4), 103-105.

Mart, C.T. (2013b).The Direct-Method: A good start to teach oral language. International Journal of Academic Research in Business and Social Sciences, 3(11), 182-184.

Mart, C.T. (2018). From communicative competence to language development. International Journal of English Linguistics, 892), 163-167. Doi: 10.5539/ijel.v8n2p163

Michel, J. F. (2005). Les 7 Profils D'apprentissage-Pour Former Et Enseigner, Organisation Eds D

Murcia M.C. (1991). Grammar pedogogy in second and foreign language. TESOL Quarterly, 25(3), 459480.

Naik, H. S. (2013). Content cum methodology of teaching English. Sapna Book House.

Oxford, R. (1989). The role of styles and strategies in second language learning. ERIC Digest. ERIC clearinghouse and linguistic Washington DC.

Richards, J. C., \& Rodgers, T. S. (2001). Approaches and methods in language teaching: A description and analysis. Cambridge, England: Cambridge University Press.

Richards, J. C., \& Schmidt, R. (2002). Longman dictionary of language teaching and applied linguistics. London, England: Pearson Education.

Rivers, W. M. (1981). Teaching foreign-language skills. The University of Chicago Press, Chicago.

Stern, H. H. (1983). Fundamental concepts of language teaching. Oxford, England: Oxford University Press. 